\title{
Evaluation of Heavy Metals Content and Human Health Risk Assessment via Consumption of Vegetables from Selected Markets in Bayelsa State, Nigeria
}

\section{Kingsley Patrick-Iwuanyanwu ${ }^{1}$ and Nganwuchu Chinyere Chioma ${ }^{2 *}$}

${ }^{1}$ Department of biochemistry, University of portharcourt. Nigeria

${ }^{2}$ Department of Pharmacognosy, Port Harcourt Polytechnic, Nigeria

\begin{abstract}
The aim of this study was to evaluate the concentration of heavy metals namely (Lead (Pb), Nickel (Ni), Cadmium $(\mathrm{Cd})$ and Chromium (Cr)) via consumption of vegetables from selected markets in Bayelsa State, Nigeria. Sixteen different vegetable samples comprising of Bitter leaves (Vernonia amygdalina), Curry leaves (Ocimum basilicum), Scent leaves (Ocimum gratissmum), Water Leaves (Talinum triangulare), Uziza (Piper guineese), Fluted pumpkin (Telferia occidetalis), Okazi (Gnetum africanum), and Okra (Abelmoschus esculentus) were digested and analyzed for heavy metals using Solar Thermo Elemental Flame Atomic Absorption Spectrophotometer (STEF-AAS). Results obtained were used to estimate the health risk of these heavy metals via consumption of the vegetable samples. The results from the study showed that the heavy metal concentration ranged between 0.016 to $1.387 \mathrm{mg} / \mathrm{kg}, 0.028$ to $1.487 \mathrm{mg} /$ $\mathrm{kg}, 0.093$ to $3.625 \mathrm{mg} / \mathrm{kg}$ and 0.893 to $2.478 \mathrm{mg} / \mathrm{kg}$ for $\mathrm{Pb}, \mathrm{Cd}, \mathrm{Ni}$ and $\mathrm{Cr}$ respectively. The concentration of $\mathrm{Pb}$ was below permissible limit recommended by WHO/FAO. The concentration of $\mathrm{Cd}$ in $\mathrm{O}$. gratissimum and $T$. triangulare from both markets exceeded the permissible limit recommended by WHO/FAO and EC/CODEX. The concentration of $\mathrm{Ni}$ in $O$. gratissimum and $T$. occidetalis from Kpanshia market exceeded the permissible limit recommended by NAFDAC while $\mathrm{Cr}$ from both markets exceeded permissible limit recommended by European community/CODEX. The Hazard Index $(\mathrm{HI})$ values for all the samples under study were greater than $(>) 1$ which indicates that there is potential health risk to those consuming these vegetables except $A$. esculentus in Kpanshia market for adults which was less than $(<)$ 1. The Target Hazard Quotient (THQ) concentrations of $\mathrm{Pb}$ in O. gratissimum, $T$. occidetalis and $\mathrm{G}$. africanum from Kpanshia market and $\mathrm{O}$. basilicum from Swali market, $\mathrm{Cd}$ in $T$. triangulare and $\mathrm{O}$. gratissimum from both markets and $\mathrm{Ni}$ in T. occidetalis from Swali market for children only were all greater than 1 which indicates level of concern that the population may be at risk of either $\mathrm{Pb}, \mathrm{Ni}$ or $\mathrm{Cd}$ toxicity. The Estimated Daily Intake (EDI) concentrations of $\mathrm{Pb}$ in $\mathrm{O}$. gratissimum, T. occidetalis and G. africanum all from Kpanshia market, $\mathrm{Cd}$ in T. triangulare from both markets, and $\mathrm{Ni}$ in all the samples from both markets were all above the permissible tolerable daily intake (PTDI) limit as recommended by EFSA (European Food and Safety Agency) meaning that those who consume this product may be at risk. The results from the present study tends to suggest that consumption of vegetables from both markets under study in Bayelsa state could be one of the contributory factors to the heavy metal burden among consumers due to their frequent consumption.
\end{abstract}

Keywords: Air pollution; Sewage sludge; Chemical properties; Organic matter; Bioavailability

\section{Introduction}

Vegetables constitute an important part of the human diet since they contain carbohydrates, proteins, vitamins, minerals as well as trace elements. The contamination of vegetables with heavy metals due to soil and atmospheric contamination poses a threat to its quality and safety. Dietary intake of heavy metals also poses risk to animals and human health. High concentrations of heavy metals $(\mathrm{Cu}, \mathrm{Cd}$ and $\mathrm{Pb})$ in fruits and vegetables were related to high prevalence of upper gastrointestinal cancer. Many anthropogenic sources such as waste incineration, industrial processes and most importantly, vehicular traffic emit heavy metals into the atmosphere. Regulations have been set up in many countries and for different industrial set up to control the emission of heavy metals.

The uptake and bioaccumulation of heavy metals in vegetables are influenced by many factors such as climate, atmosphere depositions, the concentrations of heavy metals in soil, the nature of soil and the degree of maturity of the plants at harvest [1,2]. Air pollution may pose a threat to post-harvest vegetables during transportation and marketing causing elevated levels of heavy metals in vegetables. Elevated levels of heavy metals in vegetables are reported which such as long term uses of treated or untreated waste water. Other anthropogenic sources of heavy metals include the addition of manures, sewage sludge, fertilizers and pesticides which may affect the update of heavy metals by modifying the physico-chemical properties of the soil such as $\mathrm{pH}$, organic matter, bioavailability of heavy metals in the soil [3]. Whatmuff and McBride [4,5] found that increasing concentrations of heavy metals in soil increased the crop uptake. Cultivation areas near highways are also exposed to atmospheric pollution in the form of metal containing aerosols. These aerosols can be deposited on soil and absorbed by vegetables, or alternatively deposited on leaves and fruits and then absorbed. High accumulation of $\mathrm{Pb}, \mathrm{Cr}$ and $\mathrm{Cd}$ in leafy vegetables due to atmospheric depositions has been reported by Voutsa et al. and De Nicola et al. $[2,6]$. The levels of heavy metals $(\mathrm{Zn}, \mathrm{Mn}, \mathrm{Cu}$ and $\mathrm{Pb})$ in vegetable (Talinum triangulare) collected from selected markets of bayelsa, Nigeria were found to be high. The partitioning of heavy metals is well known, with accumulation of greater concentrations in the edible portions of leafy or root crops than the storage organs or fruits [7-9].

*Corresponding author: Chinyere Chioma Nganwuchu, Department of Pharmacognosy, Port Harcourt Polytechnic, Nigeria, Tel: 234806721 3049; Email: nganwuchuchinyere@gmail.com

Received: August 28, 2017; Accepted: September 11, 2017; Published September 20, 2017

Citation: Patrick-Iwuanyanwu K and Chioma NC (2017) Evaluation of Heavy Metals Content and Human Health Risk Assessment via Consumption of Vegetables from Selected Markets in Bayelsa State, Nigeria. Biochem Anal Biochem 6: 332. doi: 10.4172/2161-1009.1000332

Copyright: (c) 2017 Patrick-Iwuanyanwu K, et al. This is an open-access article distributed under the terms of the Creative Commons Attribution License, which permits unrestricted use, distribution, and reproduction in any medium, provided the original author and source are credited. 
Citation: Patrick-Iwuanyanwu K and Chioma NC (2017) Evaluation of Heavy Metals Content and Human Health Risk Assessment via Consumption of Vegetables from Selected Markets in Bayelsa State, Nigeria. Biochem Anal Biochem 6: 332. doi: 10.4172/2161-1009.1000332

Page 2 of 6

Urban activities may significantly contribute to elevated heavy metal loads in atmospheric deposits and consequently in the edible portion of the vegetables. Thus, the present study was conducted with the objectives to investigate the accumulation of heavy metals $(\mathrm{Cu}$, $\mathrm{Zn}, \mathrm{Pb}$ ) on the vegetables. Water-washing by shaking mechanically removes much of the particulate found on the leaf surfaces, allowing the fractions of particle-bound heavy metals to be estimated. This study therefore, aimed to distinguish the water-removable fraction of heavy metals and the fraction present in leaves, potentially supplying useful information on the pollutant fraction damaging to leaf physiological processes. Heavy metals enter the body system through food, air, water and bio-accumulate over a period of time. Excess heavy metal accumulation in the environment is capable to have toxicological implications in human. Heavy metal pollution is of significant ecological/environmental concern this is due to the fact that they are not easily biodegradable or metabolized, thus precipitating far reaching effects on the biological system.

The aim of this study is to analyze the selected vegetables for the level of heavy metals. Also carry out health impact assessment at the various locations in order to suggest necessary measure that can alleviate the effects of such environmental contamination.

\section{Materials and Methods}

The present study was carried out in Bayelsa state located in the South-South region Nigeria. The climate of the region is tropical with two distinct seasons i.e., dry and rainy. The dry season (November to April) is associated with high temperature during the day ranging from a minimum of $30^{\circ} \mathrm{C}$ to a maximum of $36^{\circ} \mathrm{C}$. Rainy season starts in May and continue till end of October. During the rainy season, the temperature varies from a minimum of $24^{\circ} \mathrm{C}$ to a maximum of $32^{\circ} \mathrm{C}$.

Bayelsa is one of the riverine cities of Nigeria. There are several retailed markets in Bayelsa.

\section{Vegetable markets}

Two multipurpose retail markets were sampled. The magnitude of urban activities such as industrial, commercial buying and selling, varied between the sampling locate.

\section{Leafy vegetables}

Sixteen different vegetable samples comprising of Bitter leaves (Vernonia amygdalina), Curry leaves (Ocimum basilicum), Scent leaves (Ocimum gratissmum), Water Leaves (Talinum triangulare), Uziza (Piper guineese), Fluted pumpkin (Telferia occidetalis), Okazi (Gnetum africanum), and Okra (Abelmoschus esculentus) each were collected from Kpanshia and Swali markets in Bayelsa state, Nigeria.

\section{Pretreatment and washing of samples}

After collection, samples were brought to the laboratory and processed further for analysis. Edible portions of the samples were used while bruised or rotten portions were removed. The edible portions of the collected vegetable samples were properly washed to eliminate adsorbed dust particles. The vegetables were air-dried for twelve (12) days under hygienic condition to prevent further contamination from in-situ environment.

\section{Digestion}

A total volume of $100 \mathrm{ml}$ of $\mathrm{H}_{2} \mathrm{SO}_{4}, \mathrm{HNO}_{3}$, and $\mathrm{HClO}_{4}$ in the ratio of 40\%:40\%:20\% was mixed together. A portion (5 g) of the samples was weighed and digested with a $2 \mathrm{ml}$ of the mixed acid to each of the samples in a kjedahl flask. The samples were then digested in a fume cupboard with hot plate until white fumes appeared. After that, the solution was then cooled, filtered and transferred into a $100-\mathrm{ml}$ volumetric flask and made up to mark with distilled water.

\section{Heavy metal health risk assessment}

To assess the health risks associated with the ingestion of heavy metals from vegetables, the Estimated Daily Intake (EDI) of heavy metals, Target Hazard Quotient (THQ), Hazard Index (HI) and Total Carcinogenic Risk (CR) were calculated.

\section{Estimated Daily Intake (EDI)}

$\mathrm{EDI}=\frac{\text { Cmetal } \times \text { Dfoodintake }}{\text { BWavergae }}$

Where:

$\mathrm{C}_{\text {metal }}$ is the metal concentration in vegetable in $\mathrm{mg} / \mathrm{kg}$,

$\mathrm{D}_{\text {food intake }}$ is the daily intake of food in $\mathrm{kg}_{\text {person }}{ }^{-1}$ and

$\mathrm{BW}_{\text {average }}$ is average body weight in $\mathrm{kg}$ person ${ }^{-1}$

An average daily consumption of $0.2 \mathrm{~kg}$ of vegetable was assumed in this study. This value was adopted because vegetable constitute a major part of the diet. Average adult body weight was considered to be $60 \mathrm{~kg}$.

\section{Non-carcinogenic health effect}

Target hazard quotient: Non-carcinogenic risk estimation of heavy metals consumption was determined using THQ values. THQ is a ratio of the determined dose of a toxicant to a reference dose considered harmful. If the ratio is equal to or greater than 1 , an exposed population is at risk. THQ values were calculated using the following formula below [10].

$$
\mathrm{THQ}=\frac{\mathrm{Efr} \times \mathrm{ED} \times \mathrm{FIR} \times \mathrm{C}}{\mathrm{RfDo} \times \text { Baverageweight } \times \mathrm{ATn} \times 10^{-3}}
$$

Where

Efr is exposure frequency in 156 days year ${ }^{-1}$,

$\mathrm{ED}$ is exposure duration in 56 years equivalent to an average lifetime,

FIR is average daily consumption in $\mathrm{Kg}_{\text {person }}{ }^{-1}$ day $^{-1}$,

$\mathrm{C}$ is concentration of metal in food sample in $\mathrm{mg} / \mathrm{kg}$

$\mathrm{Rf}$ Do is reference dose in $\mathrm{mg} / \mathrm{Kg}$ day $^{-1}$ and

ATn is average exposure time for non-carcinogens in days (156 $\times 56)$.

The following reference doses were used $(\mathrm{Cd}=0.001 \mathrm{mg} / \mathrm{kg}, \mathrm{Ni}=0.02$ $\mathrm{mg} / \mathrm{kg}, \mathrm{Cr}=1.5 \mathrm{mg} / \mathrm{kg}, \mathrm{Pb}=0.0035 \mathrm{mg} / \mathrm{kg})[11,12]$.

Calculation of hazard index: Hazard index is used to evaluate the potential risk to human health when more than one heavy metal is involved. Hazard index was calculated as the sum of hazard quotients (HQs) [13-16]. Since different pollutants can cause similar adverse health effects, it is often appropriate to combine HQs associated with different substances [17-21].

$$
\mathrm{HI}=\Sigma \mathrm{THQ}\left(\mathrm{THQ}_{1}+\mathrm{THQ}_{2}+\mathrm{THQ}_{3} \ldots \ldots \ldots . \mathrm{THQ}_{\mathrm{n}}\right)
$$

\section{Carcinogenic health effect}

Incremental lifetime cancer risk is the lifetime probability of an 
Citation: Patrick-Iwuanyanwu K and Chioma NC (2017) Evaluation of Heavy Metals Content and Human Health Risk Assessment via Consumption of Vegetables from Selected Markets in Bayelsa State, Nigeria. Biochem Anal Biochem 6: 332. doi: 10.4172/2161-1009.1000332

individual developing any type of cancer due to carcinogenic daily exposure to a contaminant over a life time. The ILCR is obtained using the Cancer Slope Factor (CSF) which evaluates the probability of an individual developing cancer from oral exposure to contaminant levels over a period of a lifetime as described by ATSDR in 2010 and it is contaminant specific [22-30]. Ingestion cancer slope factors are expressed in units of ( $\mathrm{mg} / \mathrm{kg} /$ day).

The cancer risk was calculated using the equation below;

Carcinogenic risk=EDI $\times \mathrm{CSF}_{\text {ing }}$

Where:

EDI is the estimated daily intake of each heavy metal $(\mathrm{mg} / \mathrm{kg} /$ day $)$

$\mathrm{CSF}_{\text {ing }}$ is ingestion cancer slope factor $(\mathrm{mg} / \mathrm{kg} / \text { day })^{-1}(\mathrm{Cd}=0.38$, $\mathrm{Pb}=0.0085$ )

US EPA, 2011 states that $10^{-6}$ ( 1 in $\left.1,000,000\right)$ to $10^{-4}(1$ in 10,000$)$ represent a range of permissible predicted lifetime risks for carcinogens. Chemical for which the risk factor falls below $10^{-6}$ may be eliminated from further consideration as a chemical of concern.

\section{Results}

\section{Concentration $(\mathrm{mg} / \mathrm{kg})$ of heavy metals in selected vegetables}

The results of different vegetable samples analyzed for lead, cadmium, nickel, and chromium are shown in Table 1 . The results from the study showed that the concentration of $\mathrm{Pb}$ ranged between 0.016 to $1.387 \mathrm{mg} / \mathrm{kg}$ with the highest level recorded in G. africanum (1.387 $\mathrm{mg} / \mathrm{kg})$ followed by O. gratissimum $(1.358 \mathrm{mg} / \mathrm{kg})$ and T. occidetalis $(1.163 \mathrm{mg} / \mathrm{kg})$ all in Kpanshia market while the lowest level $\mathrm{Pb}$ was recorded in A. esculentus from Swali market $(0.016 \mathrm{mg} / \mathrm{kg})$. Cadmium concentration ranged from 0.028 to $1.487 \mathrm{mg} / \mathrm{kg}$ with the highest seen in T. triangulare (1.487) from Kpanshia market [31-36]. However, $V$. amygdalina from both markets and O. basilicum from Kpanshia market were below detectable limit $(\mathrm{BDL}<0.001)$. Nickel concentration ranged from 0.093 to $3.625 \mathrm{mg} / \mathrm{kg}$. The highest concentration of $\mathrm{Ni}$ was observed in O. gratissimum $(3.625 \mathrm{mg} / \mathrm{kg}$ ) from Kpanshia market while the lowest level was recorded in O. gratissimum (0.093) in Swali market [37-43]. Cr concentration in the samples ranged from 0.893 to 2.478 $\mathrm{mg} / \mathrm{kg}$ with the highest concentration recorded in T. triangulare $(2.478$ $\mathrm{mg} / \mathrm{kg}$ ) while the lowest level was recorded in G. africanum $(0.893 \mathrm{mg} /$ $\mathrm{kg}$ ) both from Kpanshia market.

\section{Estimated daily intake of metals for adults $(\mathrm{mg} / \mathrm{kg})$}

The results of the EDI for adults are shown in Table 2. The result of $\mathrm{Pb}$ was within the range of 0.001 to $0.007 \mathrm{mg} / \mathrm{kg}$. However, $A$. esculentus from both Kpanshia and Swali markets, T. occidetalis and G. africanum in Swali market, $\mathrm{Pb}$ was found to be below detectable limit (4E-04, 8E-05, 8E-04 and 8E-04 mg/kg respectively) [44-49].

Cadmium ranged between 0.002 to $0.007 \mathrm{mg} / \mathrm{kg}$ with the highest concentration recorded in T. triangulare $(0.007 \mathrm{mg} / \mathrm{kg})$ from Kpanshia market. However, concentration of V. amygdalina, O. basilicum from Kpanshia market and V. amygdalina from Swali market were below detectable limits. The result of $\mathrm{Ni}$ was within the range of 0.002 to $0.018 \mathrm{mg} / \mathrm{kg}$ with $O$. gratissimum from Kpanshia market recording the highest value $(0.018 \mathrm{mg} / \mathrm{kg})$ while $O$. gratissimum from Swali market was below detectable limit [50-60].

Chromium value ranged between 0.004 to $0.012 \mathrm{mg} / \mathrm{kg}$. The highest concentration was observed in T. triangulare $(0.012 \mathrm{mg} / \mathrm{kg})$ from Swali market.

\section{Estimated daily intake of metals for children $(\mathrm{mg} / \mathrm{kg})$}

The results of the EDI for children are shown in Table 3. The concentration of $\mathrm{Pb}$ ranged between 0.001 to $0.012 \mathrm{mg} / \mathrm{kg}$. Calculated EDI for $\mathrm{Pb}$ in children was highest in O. gratissimum $(0.012 \mathrm{mg} / \mathrm{kg})$ from Kpanshia market. Cadmium ranged from 0.001 to $0.013 \mathrm{mg} / \mathrm{kg}$ with $T$. triangulare recording the highest value $(0.013 \mathrm{mg} / \mathrm{kg})$. Calculated EDI for $\mathrm{Ni}$ ranged between 0.004 to $0.032 \mathrm{mg} / \mathrm{kg}$ with the highest value recorded in O. gratissimum $(0.032 \mathrm{mg} / \mathrm{kg})$ from Kpanshia market. The EDI for $\mathrm{Cr}$ in children ranged between 0.008 to $0.022 \mathrm{mg} / \mathrm{kg}$ with the highest value recorded in T. triangulare $(0.022 \mathrm{mg} / \mathrm{kg})$ from Kpanshia market (Tables 1-3). The non-carcinogenic risk of four heavy metals exposure to consumption of L. flammea from Bayelsa State are presented in Table 4.

\section{Target hazard quotient and hazard index of heavy metals for adults}

The THQ value greater than (>) 1 indicates health concern.

The non-carcinogenic risk of four heavy metals exposure to consumption of vegetables from Kpanshia and Swali markets in Bayelsa state are presented in Table 5. The THQ for $\mathrm{Pb}$ ranged from of

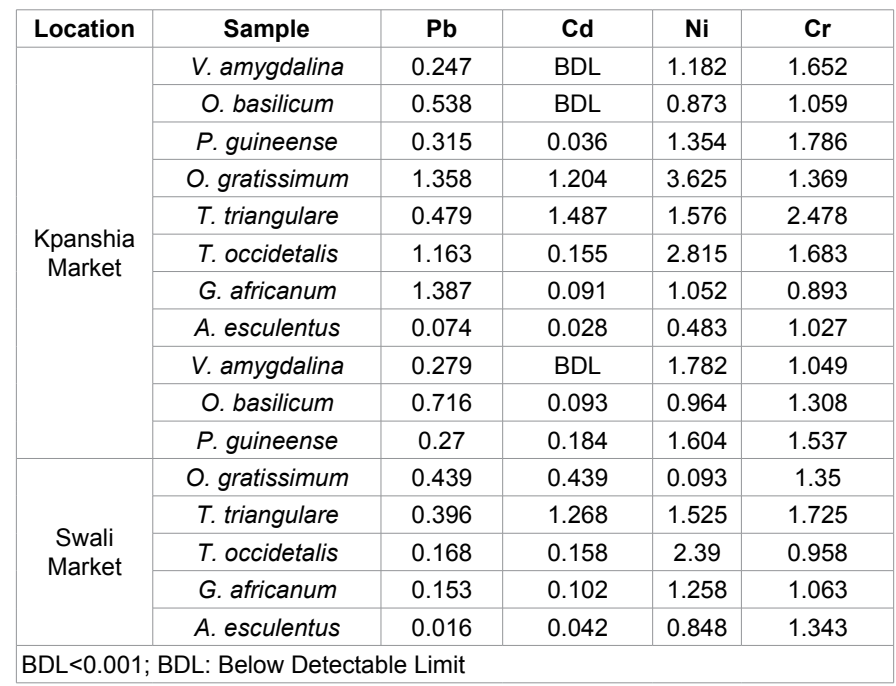

Table 1: Concentration of heavy metals in $\mathrm{mg} / \mathrm{kg}$ in selected vegetable samples.

\begin{tabular}{|c|c|c|c|c|c|}
\hline Location & Sample & $\mathbf{P b}$ & $\mathbf{C d}$ & $\mathbf{N i}$ & $\mathbf{C r}$ \\
\hline \multirow{5}{*}{ Kpanshia Market } & V. amygdalina & 0.001 & 0 & 0.006 & 0.008 \\
\cline { 2 - 6 } & O. basilicum & 0.003 & 0 & 0.004 & 0.005 \\
\cline { 2 - 6 } & P. guineense & 0.002 & $2.00 \mathrm{E}-04$ & 0.007 & 0.009 \\
\cline { 2 - 6 } & O. gratissimum & 0.007 & 0.006 & 0.018 & 0.007 \\
\cline { 2 - 6 } & T. triangulare & 0.002 & 0.007 & 0.008 & 0.012 \\
\cline { 2 - 6 } & T. occidetalis & 0.006 & $8.00 \mathrm{E}-04$ & 0.014 & 0.008 \\
\cline { 2 - 6 } & G. africanum & 0.007 & $5.00 \mathrm{E}-04$ & 0.005 & 0.004 \\
\cline { 2 - 6 } & A. esculentus & $4.00 \mathrm{E}-04$ & $1.00 \mathrm{E}-04$ & 0.002 & 0.005 \\
\cline { 2 - 6 } & V. amygdalina & 0.001 & 0 & 0.009 & 0.005 \\
\cline { 2 - 6 } & O. basilicum & 0.004 & $5.00 \mathrm{E}-04$ & 0.005 & 0.007 \\
\cline { 2 - 6 } & P. guineense & 0.001 & $9.00 \mathrm{E}-04$ & 0.008 & 0.008 \\
\hline \multirow{5}{*}{ Swali Market } & O. gratissimum & 0.002 & 0.002 & $5.00 \mathrm{E}-04$ & 0.007 \\
\cline { 2 - 6 } & T. triangulare & 0.002 & 0.006 & 0.008 & 0.009 \\
\cline { 2 - 6 } & T. occidetalis & $8.00 \mathrm{E}-04$ & $8.00 \mathrm{E}-04$ & 0.012 & 0.005 \\
\cline { 2 - 6 } & G. africanum & $8.00 \mathrm{E}-04$ & $5.00 \mathrm{E}-04$ & 0.006 & 0.005 \\
\cline { 2 - 6 } & A. esculentus & $8.00 \mathrm{E}-05$ & $2.00 \mathrm{E}-04$ & 0.004 & 0.007 \\
\hline
\end{tabular}

Table 2: Estimated Daily Intake (EDI) of heavy metals in $\mathrm{mg} / \mathrm{kg}$ for adults $(70 \mathrm{~kg}$ ) from consumption of vegetables. 
Citation: Patrick-Iwuanyanwu K and Chioma NC (2017) Evaluation of Heavy Metals Content and Human Health Risk Assessment via Consumption of Vegetables from Selected Markets in Bayelsa State, Nigeria. Biochem Anal Biochem 6: 332. doi: 10.4172/2161-1009.1000332

Page 4 of 6

\begin{tabular}{|c|c|c|c|c|c|}
\hline Location & Sample & $\mathbf{P b}$ & $\mathbf{C d}$ & $\mathbf{N i}$ & $\mathbf{C r}$ \\
\hline \multirow{5}{*}{ Kpanshia Market|} & V. amygdalina & 0.002 & 0 & 0.01 & 0.015 \\
\cline { 2 - 6 } & O. basilicum & 0.005 & 0 & 0.008 & 0.009 \\
\cline { 2 - 6 } & P. guineense & 0.003 & $3.00 \mathrm{E}-04$ & 0.012 & 0.016 \\
\cline { 2 - 6 } & O. gratissimum & 0.012 & 0.011 & 0.032 & 0.012 \\
\cline { 2 - 6 } & T. triangulare & 0.004 & 0.013 & 0.014 & 0.022 \\
\cline { 2 - 6 } & T. occidetalis & 0.01 & 0.001 & 0.025 & 0.015 \\
\cline { 2 - 6 } & G. africanum & 0.012 & $8.00 \mathrm{E}-04$ & 0.009 & 0.008 \\
\cline { 2 - 6 } & A. esculentus & $7.00 \mathrm{E}-04$ & $2.00 \mathrm{E}-04$ & 0.004 & 0.009 \\
\cline { 2 - 6 } & V. amygdalina & 0.002 & 0 & 0.016 & 0.009 \\
\cline { 2 - 6 } & O. basilicum & 0.006 & $8.00 \mathrm{E}-04$ & 0.008 & 0.012 \\
\cline { 2 - 6 } & P. guineense & 0.002 & 0.002 & 0.014 & 0.014 \\
\hline & O. gratissimum & 0.004 & 0.004 & $8.00 \mathrm{E}-04$ & 0.012 \\
\cline { 2 - 6 } & T. triangulare & 0.003 & 0.011 & 0.013 & 0.015 \\
\cline { 2 - 6 } & T. occidetalis & 0.001 & 0.001 & 0.021 & 0.008 \\
\cline { 2 - 6 } & G. africanum & 0.001 & $9.00 \mathrm{E}-04$ & 0.011 & 0.009 \\
\cline { 2 - 6 } & A. esculentus & $1.00 \mathrm{E}-04$ & $4.00 \mathrm{E}-04$ & 0.007 & 0.012 \\
\hline
\end{tabular}

Table 3: Estimated Daily Intake (EDI) of heavy metals $(\mathrm{mg} / \mathrm{kg})$ for children $(24 \mathrm{~kg})$ from consumption of vegetables.

\begin{tabular}{|c|c|c|c|c|c|c|}
\hline Location & Samples & $\mathbf{P b}$ & $\mathbf{C d}$ & $\mathbf{N i}$ & $\mathbf{C r}$ & $\mathbf{H I}$ \\
\hline \multirow{5}{*}{$\begin{array}{c}\text { Kpanshia } \\
\text { Market }\end{array}$} & V. amygdalina & 0.353 & 0 & 0.296 & 0.006 & 0.654 \\
\cline { 2 - 7 } & O. basilicum & 0.769 & 0 & 0.218 & 0.004 & 0.99 \\
\cline { 2 - 7 } & P. guineense & 0.45 & 0.18 & 0.339 & 0.006 & 0.974 \\
\cline { 2 - 7 } & O. gratissimum & 1.94 & 6.02 & 0.906 & 0.005 & 8.871 \\
\cline { 2 - 7 } & T. triangulare & 0.684 & 7.435 & 0.394 & 0.008 & 8.522 \\
\cline { 2 - 7 } & T. occidetalis & 1.661 & 0.775 & 0.704 & 0.006 & 3.146 \\
\cline { 2 - 7 } & G. africanum & 1.981 & 0.455 & 0.263 & 0.003 & 2.702 \\
\cline { 2 - 7 } & A. esculentus & 0.106 & 0.14 & 0.121 & 0.003 & 0.37 \\
\cline { 2 - 7 } & V. amygdalina & 0.399 & 0 & 0.446 & 0.003 & 0.848 \\
\cline { 2 - 7 } & O. basilicum & 1.023 & 0.465 & 0.241 & 0.004 & 1.733 \\
\cline { 2 - 7 } & P. guineense & 0.386 & 0.92 & 0.401 & 0.005 & 1.712 \\
\cline { 2 - 7 } & O. gratissimum & 0.627 & 2.195 & 0.023 & 0.004 & 2.85 \\
\hline & T. triangulare & 0.566 & 6.34 & 0.381 & 0.006 & 7.293 \\
\cline { 2 - 7 } & T. occidetalis & 0.24 & 0.79 & 0.598 & 0.003 & 1.631 \\
\cline { 2 - 7 } & G. africanum & 0.219 & 0.51 & 0.315 & 0.004 & 1.047 \\
\cline { 2 - 7 } & A. esculentus & 0.023 & 0.21 & 0.212 & 0.004 & 0.449 \\
\hline
\end{tabular}

Table 4: Target hazard quotient (THQ) and Hazard index (HI) for adult exposed to vegetables contaminated with heavy metals.

\begin{tabular}{|c|c|c|c|c|c|c|}
\hline Location & Samples & $\mathbf{P b}$ & $\mathbf{C d}$ & $\mathbf{N i}$ & $\mathbf{C r}$ & $\mathbf{H I}$ \\
\hline \multirow{4}{*}{$\begin{array}{c}\text { Kpanshia } \\
\text { market }\end{array}$} & V. amygdalina & 0.621 & 0 & 0.52 & 0.01 & 1.151 \\
\cline { 2 - 7 } & O. basilicum & 1.353 & 0 & 0.384 & 0.006 & 1.743 \\
\cline { 2 - 7 } & P. guineense & 0.792 & 0.317 & 0.596 & 0.01 & 1.715 \\
\cline { 2 - 7 } & O. gratissimum & 3.414 & 10.6 & 1.595 & 0.008 & 15.61 \\
\cline { 2 - 7 } & T. triangulare & 1.204 & 13.09 & 0.693 & 0.015 & 15 \\
\cline { 2 - 7 } & T. occidetalis & 2.924 & 1.364 & 1.239 & 0.01 & 5.537 \\
\cline { 2 - 7 } & G. africanum & 3.487 & 0.801 & 0.463 & 0.005 & 4.756 \\
\cline { 2 - 7 } & A. esculentus & 0.186 & 0.246 & 0.213 & 0.006 & 0.651 \\
\cline { 2 - 7 } & V. amygdalina & 0.701 & 0 & 0.784 & 0.006 & 1.492 \\
\cline { 2 - 7 } & O. basilicum & 1.8 & 0.818 & 0.424 & 0.008 & 3.05 \\
\cline { 2 - 7 } & P. guineense & 0.679 & 1.619 & 0.706 & 0.009 & 3.013 \\
\hline \multirow{5}{*}{ Swali Market } & O. gratissimum & 1.104 & 3.863 & 0.041 & 0.008 & 5.016 \\
\cline { 2 - 7 } & T. triangulare & 0.996 & 11.16 & 0.671 & 0.01 & 12.84 \\
\cline { 2 - 7 } & T. occidetalis & 0.422 & 1.39 & 1.052 & 0.006 & 2.87 \\
\cline { 2 - 7 } & G. africanum & 0.385 & 0.898 & 0.554 & 0.006 & 1.842 \\
\cline { 2 - 7 } & A. esculentus & 0.04 & 0.37 & 0.373 & 0.008 & 0.791 \\
\hline
\end{tabular}

Table 5: Target hazard quotient (THQ) and Hazard index (HI) for children exposed to vegetables contaminated with heavy metals.

0.023 to $1.981 \mathrm{mg} / \mathrm{kg}$ with the highest value recorded in G. africanum $(1.981 \mathrm{mg} / \mathrm{kg})$ in adult whereas calculated THQ values in children ranged between 0.040 to $3.487 \mathrm{mg} / \mathrm{kg}$ with G. africanum $(3.487 \mathrm{mg} / \mathrm{kg})$ recording the highest.

THQ value of Cd ranged between 0.180 to $7.435 \mathrm{mg} / \mathrm{kg}$ and 0.317-13.09 $\mathrm{mg} / \mathrm{kg}$ for adult and children respectively. However, $T$. triangulare from Kpanshia market recorded the highest THQ values of 7.435 and $13.09 \mathrm{mg} / \mathrm{kg}$ for both adult and children respectively [61-65].

The THQ value for Ni ranged between 0.023 to $0.906 \mathrm{mg} / \mathrm{kg}$ and 0.041 to $1.595 \mathrm{mg} / \mathrm{kg}$ for adult and children respectively. However, the highest values adults and children were seen in O. gatissimum $(0.906$ $\mathrm{mg} / \mathrm{kg}$ and $1.595 \mathrm{mg} / \mathrm{kg}$ ) from Swali and Kpanshia markets respectively.

The THQ value of $\mathrm{Cr}$ was within the range 0.003 to $0.008 \mathrm{mg} /$ $\mathrm{kg}$ and 0.006 to $0.015 \mathrm{mg} / \mathrm{kg}$ for adult and children respectively. The highest value was recorded in T. triangulare $(0.008$ and $0.015 \mathrm{mg} / \mathrm{kg}$ ) in both adult and children respectively from Kpanshia market.

On the other hand, the result of HI of adults and children from both Kpanshia and Swali market were in the range 0.370 to $8.871 \mathrm{mg} /$ $\mathrm{kg}$ and 0.791 to $15.61 \mathrm{mg} / \mathrm{kg}$ respectively. The highest $\mathrm{HI}$ value in adult was recorded in 0. gratissimum $(8.871 \mathrm{mg} / \mathrm{kg}$ ) whereas the highest HI value in children was recordedin O. gratissimum $(15.61 \mathrm{mg} / \mathrm{kg})$ from Swali market (Tables 4 and 5)

\section{Discussion}

The intake of food contaminated with chemicals may result to intoxication that can be described as acute or when the disease appears after a latent period of time and long term or chronic intoxications. Ingestion of contaminated food is the main route of human exposure to these toxic compounds accounting for more than ninety percent compared to other routes. The present study has highlighted the contamination profile of vegetables commonly consumed from selected major markets in Bayelsa state, Nigeria and the possible public health implications.

Lead concentration in the samples under study from both Kpanshia and Swali markets was lower than the $2.0 \mathrm{mg} / \mathrm{kg}$ value as recommended by $\mathrm{WHO} / \mathrm{FAO}$. Among all samples analyzed for $\mathrm{Pb}, \mathrm{O}$. basilicum, $\mathrm{O}$. gratissimum, T. occidetalis and G. africanum all from Kpanshia market were above $0.3 \mathrm{mg} / \mathrm{kg}$ as recommended by European communities (Commission of the European Communities, 2001). Lead is known to induce reduced cognitive development and intellectual performance in children and cardiovascular disease and increased blood pressure in adults (European Communities, 2001).

The concentration of Cadmium in the samples collected from both Kpanshia and Swali markets showed that $\mathrm{Pb}$ concentrations in O. gratissimum and T. triangulare from both Kpanshia and Swali markets exceeded the permissible limit of $1.0 \mathrm{mg} / \mathrm{kg}$ and $0.2 \mathrm{mg} / \mathrm{kg}$ as recommended by $\mathrm{WHO} / \mathrm{FAO}$ and EC/CODEX respectively. Cadmium has been reported to accumulate in the human body and hence induce kidney dysfunction, skeletal damage and reproductive deficiencies (EC, 2001).

Nickel concentration in the samples from both Kpanshia and Swali markets showed that levels recorded in O. gratissimum and T. occidetalis exceeded the permissible limit of $2.7 \mathrm{mg} / \mathrm{kg}$ recommended by NAFDAC. Inhaled nickel carbonyl, a carcinogenic gas that results from the action of nickel with heated carbon monoxide, from cigarette smoke, car exhaust, and some industrial wastes is very toxic. Nickel allergy can also cause systematic reactions.

The concentration of $\mathrm{Cr}$ in the samples collected from Kpanshia and Swali markets exceeded the European Community/CODEX standard 
Citation: Patrick-Iwuanyanwu K and Chioma NC (2017) Evaluation of Heavy Metals Content and Human Health Risk Assessment via Consumption of Vegetables from Selected Markets in Bayelsa State, Nigeria. Biochem Anal Biochem 6: 332. doi: 10.4172/2161-1009.1000332

Page 5 of 6

of $0.3 \mathrm{mg} / \mathrm{kg}$. Chromium (III) is an essential nutrient that helps the body use sugar, protein and fat but Chromium (VI) is carcinogenic (Institute of Medicine, 2002). Adverse health effects may arise from excessive amount of chromium (III) (Agency for Toxic Substances and Disease Registry, 2004). There is no upper tolerable intake level for chromium according to the Institute of Medicine but the AI of chromium for women and men 51 to 70 years old is $20 \mathrm{mg} /$ day and $30 \mathrm{mg} /$ day respectively. Deficiency of Cr results in impaired growth and disturbances in glucose, lipid and protein metabolism. However, $\mathrm{Cr}$ (IV) is carcinogenic [66-71].

\section{Discussion}

\section{Risk assessment}

Estimated daily intake of metals: The EDI is used to calculate the amount of metal taken by an adult or children per day. From the results for both adults and children, the concentrations of lead in $O$. gratissimum, T. occidetalis and G. africanum all from Kpanshia market, Cadmium in T. triangulare from both markets, and nickel in all the samples from both markets were all above the permissible tolerable daily intake (PTDI) limit as recommended by EFSA (European Food and Safety Agency) meaning that those who consume this products may be at risk while concentration on Chromium was below the PTDI thereby attracting no health risk.

\section{Hazard index}

The $\mathrm{HI}$ is the calculation which shows when a population is at risk. From the result in the present study for both adults and children, it was observed that the HI values for all the samples under study were greater than (>) 1 which indicates that there might be a potential health risk to those consuming these vegetables except for $A$. esculentus in Kpanshia market for adults which was less than $(<) 1$.

\section{Target hazard quotient}

The THQ value is a dimensionless index of risk associated with long term exposure to chemicals. From the result in the present study for both adults and children, the concentrations of $\mathrm{Pb}$ in $\mathrm{O}$. gratissimum, T. occidetalis and G. africanum from Kpanshia market and O. basilicum from Swali market, Cd in T. triangulare and O. gratissimum from both markets and $\mathrm{Ni}$ in $\mathrm{T}$. occidetalis from Swali market for children only were all greater than 1 which indicates level of concern that the population may be at risk of either $\mathrm{Pb}, \mathrm{Ni}$ or $\mathrm{Cd}$ toxicity.

\section{Conclusion}

The results from the present study tends to suggest that consumption of vegetables from both markets under study in Bayelsa state could be one of the contributory factors to the heavy metal burden among consumers due to their frequent consumption.

\section{Recommendation}

It is therefore necessary to monitor extensively and occasionally heavy metals in vegetables especially those grown in areas where you have oil pipes which have been vandalized as a result of war or conflict by authorized government agencies in order to safeguard the health of the population.

\section{References}

1. Scott D, Keoghan JM, Allen BE (1996) Native and low input grasses-a New Zealand high country perspective. J Agric Res 39: 499-512.

2. Voutsa D, Grimanis A, Samara C (1996) Trace elements in vegetables grown in an industrial area in relation to soil and air particulate matter. Environ Pollut 94: 325-335

3. Yusuf KA, Osibanjo O (2006) Trace metals in water and sediments from Ologe Lagoon, Southwestern Nigeria Pak. J Sci Ind Res 49: 88-96.

4. Whatmuff MS (2002) Applying bio-solids to acid soil in New South Wales: Are guideline soil metal limits from other countries appropriate. Aust J Soil Res 40 1041-1056.

5. McBride MB (2003) Toxic metals in sewage sludge-amended soils: Has promotion of beneficial use discounted the risks? Adv Environ Res 8: 5-19.

6. De Nicola F, Maisto G, Prati MV, Alfani A (2008) Leaf accumulation of trace elements and polycyclic aromatic hydrocarbons (PAHS) in Quercus ilex L. Environ Pollut 153: 376-383.

7. Jinadasa KBPN, Milham PJ, CA Hawkins, Cornish PSD (1997) Survey of Cd levels in vegetables and soil of greater Sydney, Australia J Environ Qual 26 924-933.

8. Lehoczky E, Szabo L, Horvath S (1998) Cadmium uptake by lettuce in different soils. Contaminat Soil Sci Plant Anal 28: 1903-1912.

9. Sharma RK, Agrawal M (2006) Effects of single and combined treatment of Cd and $\mathrm{Zn}$ on carrots: Uptake and bioaccumulation. J Plant Nutr 29: 1791-1804.

10. Singh A, Sharma RK, Agarwal M, Marshall FM (2010) Risk assessment of heavy metal toxicity through contaminated vegetables from waste water irrigated area of Varanasi, India. Trop Ecol 51: 375-387.

11. WHO (1992) Cadmium Environmental Health Criteria, Geneva: World Health Organization, Switzerland. p. 134

12. USEPA (2011) Risk-based concentration table. United State Environmenta Protection Agency, Washington, USA.

13. Abou-Arab AAK (2001) Heavy metal contents in Egyptian meat and the role of detergent washing on their levels. Food Chem Toxicol 39: 593-599.

14. Aiyelaagbe IOO, Kintomo AA (2002) Nitrogen response of fluted pumpkin (Telfairia occidentalis Hook. F) grown sole or intercropped with banana. Nutrient Cycling in Agroecosystems 64: 231-235.

15. Akinola MO, Ekiyoyo TA (2006) Accumulation of lead, cadmium and chromium in some plants cultivated along the bank of river Ribila at Odo-nla area of Ikorodu, Lagos State, Nigeria. J Environ Biol 27: 597-599.

16. Akoroda MO (1990) Ethnobotany of Telfairia occidentalis (Curcurbitacae) among Igbos of Nigeria. Economic Botany 29-39.

17. Al-Jassir MS, Shaker A, Khaliq MA (2005) Deposition of heavy metals on green leafy vegetables sold on roadsides of Riyadh City, Saudi Arabia. Bull Environ Contam Toxicol 75: 1020-1027.

18. Antonious G, Kochhar T (2009) Mobility of heavy metals from soil into hot pepper fruits: A field study. Bull Environ Contamin Toxicol 82: 59-63.

19. Anyanwu CU, Nwosu GC (2014) Assessment of the antimicrobial activity of aqueous and ethanolic extracts of Piper guineense leaves. J Med Plant Res 8: 337-439.

20. Ashok K, Upadhyaya K (2012) Tannins are Astringent. J Pharmacog Phytochem 1: 49 .

21. Ayodele JT, Ahmed A (2001) Monitoring air pollution in Kano by chemical analysis of Scots pine (Pinus sylvestris $\mathrm{L}$ ) needle for sulphur. Environmentalist 21: $145-151$

22. Baird C (2002) Environmental chemistry. Bookman. Porto Alegre. Brazil.

23. Chojnacha K, Chojnacki A, Gorecka H, Gorecki H (2005) Bio-availability of heavy metals from polluted soils to plants. Sci Total Environ 337: 175-182.

24. Cooper CB, Doyle ME, Kipp K (1991) Risks of consumption of contaminated seafood: The Quincy Bay case study. Environ Health Perspect 90:133-140.

25. Dada AA, Ifesan BOT, Fashakin JF (2013) Antimicrobial and antioxidan properties of selected local spices used. In "Kunun" Beverage in Nigeria. Acta Sci Pol Technol Alignment 4: 374

26. Dattilo AM, Miguel SG (2003) Chromium in health and disease. Nutr Today 38 121-133.

27. D'Mello JPF (2003) Food safety: Contaminants and Toxins. CABI Publishing. UK.

28. Dogheim SM, El-Ashraf MM, Gad Alla SA, Khorshid MA, Fahmy SM (2004) 
Citation: Patrick-Iwuanyanwu K and Chioma NC (2017) Evaluation of Heavy Metals Content and Human Health Risk Assessment via Consumption of Vegetables from Selected Markets in Bayelsa State, Nigeria. Biochem Anal Biochem 6: 332. doi: 10.4172/2161-1009.1000332

Page 6 of 6

Pesticides and heavy metals levels in Egyptian leafy vegetables and some aromatic medicinal plants. Food Addit Contam 21: 323-330.

29. Emebiri L, Nwufo M (1990) Pod rots of fluted pumpkin (Telfairia Occidentalis Hook. F.) in Imo State, Nigeria. International Bio-Deterioration 26: 63-68.

30. Food and Nutrition Board (2004) Dietary Reference Intakes [DRIs]: Recommended intakes for individuals. National Academy of Sciences. USA.

31. Ijeh II, Njoku OU, Ekenza EC (2004) Medicinal evaluation of Xylopia aethiopica and Ocimum gratissimum. J Medi Aroma Sci 26: 45-46.

32. Ilori M, Sheteolu AO, Omonibgelin EA, Adeneye AA (1996) Antibacterial activity of Ocimum gratissimum (Laminaceae). pp. 283-284.

33. Institute of Medicine, Food and Nutrition Board (2001) Dietary reference intakes for vitamin $\mathrm{A}$, vitamin $\mathrm{K}$, arsenic, boron, chromium, copper, iodine, iron, manganese, molybdenum, nickel, silicon, vanadium, and zinc. National Academy Press. Washington, USA.

34. Islam MR, Hoque ME, Jahiruddin M, Isalm M (2005) Heavy metal contamination of vegetables grown in Chapainawabganj, Bangladesh and its implication to daily intake for human health. Bangladesh J Agric Environ 1: 37-48.

35. Jamali MK, Kazi TG, Arain MB, Afridi H, Jalbani N, et al. (2007) Heavy metal contents of vegetables grown in soil, irrigated with mixtures of wastewater and sewage sludge in Pakistan, using ultrasonic-assisted pseudo-digestion. J Agron Crop Sci 193: 218-228.

36. Jarup L (2003) Hazards of heavy metal contamination. Br Med Bull 68: 167-82.

37. Jeevan RK, Shantaram MV (1999) Potentially toxic elements in soils treated with urban solid wastes. Indian J Environ Health 41: 364-368.

38. Kareem KT, Kareem SO, Adeyemo OJ, Egberongbe RK (2010) In vitro antimicrobial properties of Bridelia ferruginea on some clinical isolates. Agric Biol Journal of North America 3: 418-419.

39. Kaur H (2006) Department of Biotechnology and Environmental Sciences. Thapar Institute of Engineering and Technology (Deemed University). India.

40. Khairiah T, Zalifah MK, Yin YH, Aminah A (2004) The uptake of heavy metals by fruit type vegetables grown in selected agricultural areas. Pak J Biol Sci 7: 1438-1442.

41. Khan S, Cao Q, Zheng YM, Huang YZ, Zhu YG (2008) Health risks of heavy metals in contaminated soils and food crops irrigated with waste water in Beijing, China. Environment Poll 152: 686-692.

42. Kisku GC, Barman SC, Bhargava SK (2000) Contamination of soil and plants with potentially toxic elements irrigated with mixed industrial effluent and its impact on the environment. Water Air Soil Pollution 120: 121-137.

43. Kohlmeier M (2003) Nutrient Metabolism. Elsevier. San Diego. USA

44. Ladipo MK, Doherty VF, Kanife UC (2010) Phytochemical screening and antibacterial investigation of the extract of Ocimum gratissimum (Scent Leaf) On selected enterobacteriaceae. Product Agri Technol 6: 75-76.

45. Lokeshwari $\mathrm{H}$, Chandrappa GT (2006) Impact of heavy metal contamination of Bellandur Lake on soil and cultivated vegetation. Current Sci 91: 1-6.

46. Luo Y, Rimmer DL (1995) Zinc-copper interaction affecting plant growth on a metal contaminated soil. Environ Pollution 88: 79-83.

47. Maihara VA, Fávaro DIT (2006) Toxic elements 629-660.

48. Zarasvand $M$ (2008) Heavy metals in selected edible vegetables and estimation of their daily intake in Sa-nandaj, Iran. Southeast Asian J Trop Med Public Health.

49. Saxena M, Saxena J, Nema R, Singh D, Gupta A (2013) Phytochemistry of Medicinal Plants. J Pharmacog Phytochem 1: 177

50. Mapanda F, Mangwayana EN, Nyamangara J, Giller KE (2005) The effect of long term irrigation using wastewater on heavy metal contents of soils under vegetables in Harare, Zimbabwe. Agric Ecosyst Environ 107: 151-165.
51. https://www.epa.gov/risk/human-health-risk-assessment.

52. Njoku OU, Elijah JP, Agu CV, Dim NC (2011) Antioxidant properties of Ocimum gratissimum (Scent Leaf). New York Science Journal 4: 98-99.

53. Nuhu A (2000) Heavy metal determination in mango leaves (Magnifera indica) from Kano metropolis as bio-indicators of environmental pollution. Bayero University. Nigeria.

54. Nwachukwu CU, Umeh CN, Kalu IG, Okere S, Nwoko MC (2010) Identification and traditional uses of some common medicinal plants In: Ezinihitte Mbaise LGA., of Imo State. Nigeria. Report and Opinion 2: 4.

55. Oboh G, Nwanna EE, Elusiyan CA (2008) Antioxidant and Hepato-protective Properties of Telfairia occidentalis Leaf (Fluted Pumpkin). J Pharmacol Toxico 1: 167-175.

56. Nyamangara J, Mzezewa J (1999) The effects of long-term sludge application on $\mathrm{Zn}, \mathrm{Cu}, \mathrm{Ni}$ and $\mathrm{Pb}$ levels in clay loam soil under pasture grass in Zimbabwe. Agric Ecosyst Environ 73: 199-204.

57. Ogbalor B (1991) An evaluation of domestic waste water quality for irrigation of vegetable along Jakara stream. Bayero University Kano, Nigeria.

58. Onianwa PC, Adaeyemo AO, Odowu EO, Ogabiela EE (2001) Copper and zinc contents of Nigerian foods and estimates of the adult dietary intakes. J Chem 72: 89-95.

59. Radwan MA, Salama AK (2006) Market basket survey for some heavy metals in Egyptian fruits and vegetables. Food Chem Toxicol 44: 1273-1278.

60. Sekhar KC, Supriya KR, Kamala CT, Chary NS, Rao TN, et al. (2001) Speciation, accumulation of heavy metals in vegetation grown on sludge amended soils and their transfer to human food chain-a case study. Toxicol Environ Chem 82: 33-34.

61. Sobukola OP, Dairo OU (2007) Modeling drying kinetics of fever leaves (Ocimum viride) in a convective hot air dryer. Nigerian Institute of Food Science and Technology 25: 145-153.

62. Song D, Zhuang D, Jiang D, Fu J, Wang Q (2015) Integrated health risk assessment of heavy metals in Suxian County, South China. Int J Environ Res Public Health 12: 7100-7117.

63. Sharma RK, Agrawal V, Marshall FM (2007) Heavy metal contamination of soil and vegetables in suburban areas of Varanasi, India. Ecotoxicol Environ Safe 66: 258-266.

64. Adeniyi AA (1996) Determination of cadmium, copper, iron, lead, manganese and zinc in water leaf (Talinum triangulare) in dumpsites. Environ Int 22: 259-262.

65. Sinha S, Pandey K, Grupta AK, Bhatt K (2005) Accumulation of metals in vegetables and crops grown in the area irrigated with river water. Bull Environ Contaminat Toxicol 74: 210-218.

66. USEPA (2011) Risk-based concentration table. United State Environmental Protection Agency, Washington, DC.

67. Wang PF, Zhang SH, Wang C, Hou J, Guo PC, et al. (2008) Study of heavy metal in sewage sludge and in Chinese cabbage grown in soil amended with sewage sludge. African J Biotech 7: 1329-1334.

68. Wang X, Sato T, Xing B, Tao S (2005) Health risks of heavy metals to the general public in Tianjin, China via consumption of vegetables and fish. Sci Total Environ 350: 28-37.

69. Yusuf AA, Arowolo TA, Bamgbose O (2003) Cadmium, copper and nickel levels in vegetables from industrial and residential areas of Lagos City Nigeria. Food Chem Toxicol 41: 375-378

70. Zaidi MI, Asrar A, Mansoor A, Farooqui MA (2005) The heavy meta concentrations along roadside trees of Quetta and its effects on public health J Appl Sci 5: 708-711.

71. Zurera G, Estrada B, Rincon F, Pozo R (1987) Lead and cadmium contamination levels in edible vegetables. Bull Environ Contamin Toxicol 38: 805-812. 